\title{
PSYCHE
}

\begin{tabular}{lll}
\hline Vol. 78 & December, I97 I & No. 4 \\
\hline
\end{tabular}

\author{
THE BEHAVIOR OF A STINKBUG, \\ EUSCHISTUS CONSPERSUS UHLER \\ (HEMIPTERA: PENTATOMIDAE) \\ By John Alcock ${ }^{1}$ \\ Department of Psychology, University of Washington, \\ Seattle, Washington 98105
}

The small, brown-backed, pale-bellied stinkbug Euschistus conspersus Uhler is a common insect along the Pacific coast from California to British Columbia (Essig, I929). In some areas it is a pest feeding on pears and other commercially important fruits; the natural history of several of these populations has been reported by Borden, Madsen and Retan (1952). In addition aspects of the developmental cycle of this species have been studied in the laboratory (Hunter and Leigh, I965). This paper presents new information on the basking, feeding, dispersal and courtship behavior of one population of E. conspersus in Seattle, Washington.

From the middle of May to the mid-October 197 I I watched the stinkbugs which inhabited a large vacant lot near the University of Washington. This area bordered Lake Washington and was covered by marsh and field grasses, willows, alders, cattails, and a dense stand of blackberry bushes. The results which follow have been derived from field notes and photographs made throughout the observation period.

${ }^{1}$ It is a pleasure to acknowledge those who have helped in the preparation of this paper by providing me with information and ideas: Dr. Richard D. Alexander, Dr. Thomas E. Moore, Dr. Reece I. Sailer, Dr. Norman T. Davis, and Mr. Eric McPherson. Drs. G. G. E. Scudder and Thomas F. Leigh identified the stinkbug and offered assistance in a variety of ways. Dr. R. I. Sailer referred the wasp predator of $E$. conspersus to Dr. A. S. Menke, who kindly provided me with an identification. Mr. Doug Henderson identified the foodplants of the bug. Dr. John Edwards was kind enough to read the manuscript and made very useful suggestions for its improvement. This study was done while the author was supported by NSF Grant GB-28714X.

Manuscript received by the editor March 2, 1972 


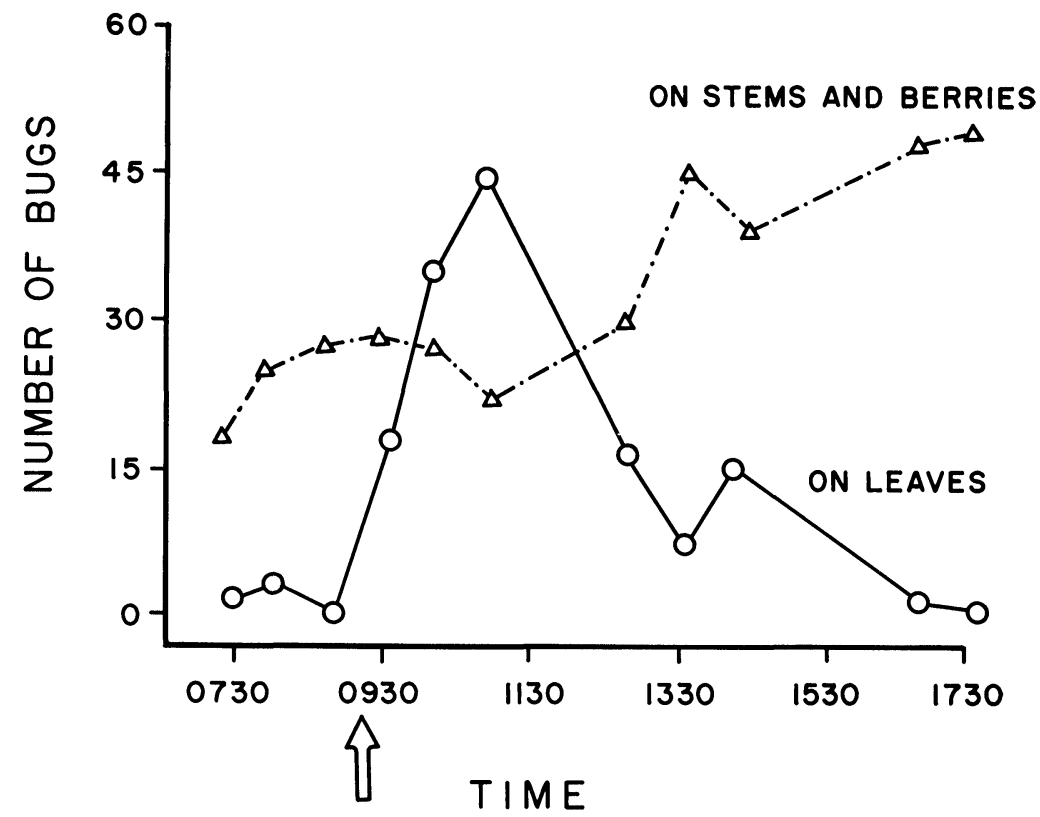

Fig. 1. The number of stinkbugs counted on leaves (solid line) and on stems and berries (broken line) on a strip of blackberry bushes at various times during the day on 5 October 1971. The arrow points to the time of appearance of the sun following a period of early morning fog.

\section{Basking Behavior}

\section{Results}

My attention was drawn to the bugs initially because so many could be found standing conspicuously on the upper surfaces of blackberry leaves in the full sun, particularly in the morning. These insects do not feed on leaves.

As Fig. I illustrates with a single day's census, the stinkbugs were rarely found on leaves until the sun had appeared in the morning. Then a very substantial proportion of the population of bugs moved quickly to places where they were fully exposed to the sun's rays (Fig. 2). Dark green blackberry leaves provide a flat heat-absorptive surface for basking. Bugs tended to flatten themselves against the leaf on which they stood. They often chose leaves which were slanted upwards so that the bug's brown back was oriented more or less at right angles to the sun. And, particularly in the early morning and late afternoon, when the sun was low, some bugs tilted their bodies 
to one side to achieve the same effect (Fig. 3). This behavior presumably increases the rapidity with which the bug is warmed by directly exposing the maximum surface area of the animal to the sun. By midday basking was on the wane (Fig. 2) although in those areas where the afternoon sun reached blackberry leaves some bugs could be seen basking in the late afternoon. (The figures are based on data collected from an area on the eastern side of the lot which was wellshaded by i6.00.)

Feeding Behavior

E. conspersus feeds on fruits and is in fact extremely catholic in its tastes (Borden, Madsen and Retan, 1952). Many bugs were watched as they fed on grasses and on the fruit and stems of the blackberry Rubus laciniatum. Although I have no quantitative evidence to confirm this point, it seemed clear that the bugs preferred, both as nymphs and adults, unripe pinkish-green blackberries to fully ripe fruit. Bugs also fed on an ornamental, Pyrecantha coccinea, and on the pods and stems of a sweet pea, Lathyrus latifolius. But by far the most remarkable choice of a foodplant was the bracken fern, Pteridium aquilinum. This plant occurred in scattered patches along the edge of the lot amidst the blackberry bushes. Both adults and nymphs were commonly found on the fern; adults were seen many times with their rostrums inserted into the stem of the plant.

Groups of adults congregated on a few ferns in the early summer and second generation bugs occurred in large numbers on almost all living ferns in the late summer. Those few ferns which had hosted bugs in the early summer turned yellow and died while the remainder on which few or no stinkbugs had been seen remained quite healthy. The stems of dying ferns were covered with small reddish marks presumed to be points of insertion of the bugs' rostrums. There was a complete die-off of all ferns in mid-September long before the first frosts. It seems likely that the stinkbugs were capable of killing their fern hosts. On the other hand, blackberry stems which supported large numbers of bugs for many days did not die back or appear injured in any way.

Feeding activity was most pronounced during the afternoon with many bugs moving from leaves to blackberry stems during this time (Fig. I).

\section{Natural Enemies}

E. conspersus was the prey of a number of wasps living in the lot. About six specimens of Dryudella sp., a tiny digger wasp, nested in an open path which passed through a grassy field bordering a large 


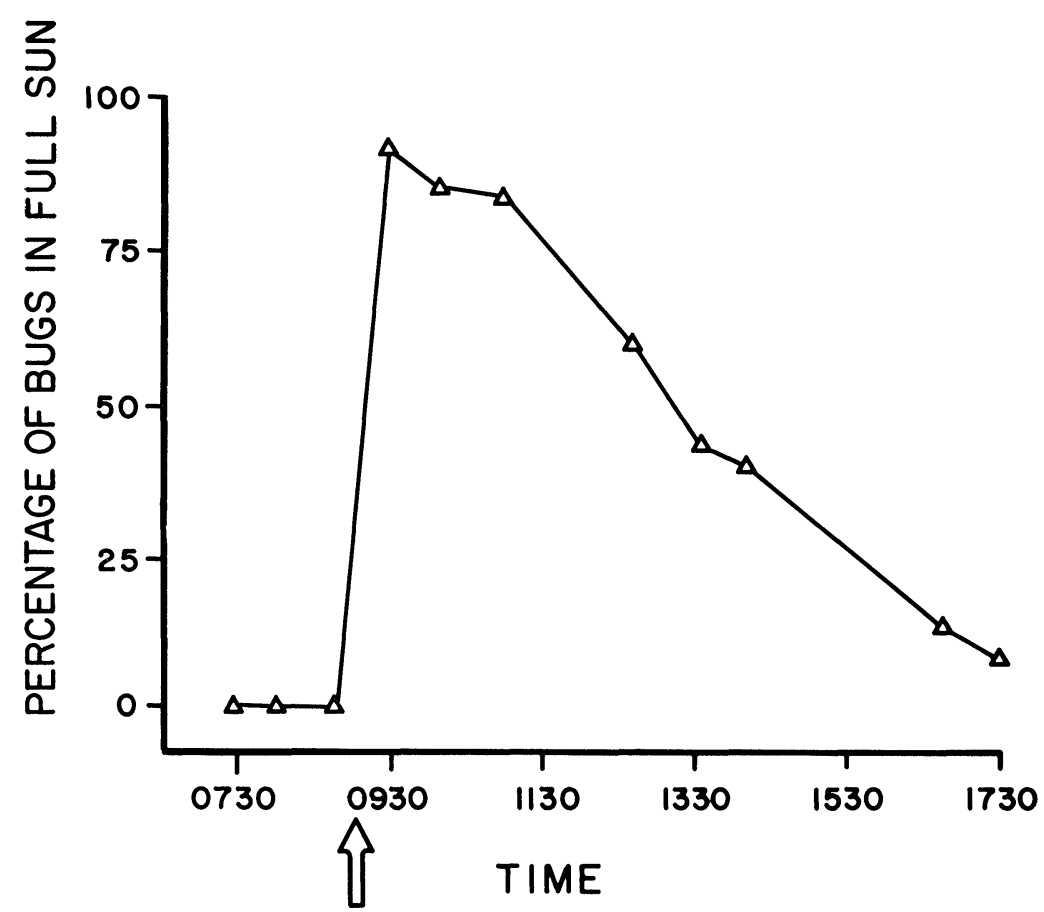

Fig. 2. The percentage of the total number of stinkbugs counted on a strip of blackberry bushes which were totally exposed to the sun. The counts took place at various times during the day on 5 October 1971. The arrow points to the time of appearance of the sun following a period of early morning fog.

blackberry patch. This species took second and third instar nymphs of $E$. conspersus as well as the nymphs of other Heteroptera. A larger unidentified black wasp was seen once with an adult bug and on another occasion as it searched the stems and undersides of leaves of blackberry plants. I watched a yellowjacket, probably Vespula pennsylvanica, macerate a late stage nymph.

The most conspicuously successful predator of the bug was the garden spider, Araneus diademata. Captured stinkbugs often appeared in the orb webs of this species in the late summer. Less commonly spiders were seen feeding on a wrapped stinkbug.

A number of other potential predators of stinkbugs, several insectivorous birds, were seen hunting in the lot. Some bird species are known to take pentatomids (Southwood and Leston, I959; Orians 
and Horn, 1969). I offered sixteen juvenile redwinged blackbirds (Agelaius phoeniceus) two live E. conspersus adults. Nine of the birds ate both bugs, although usually not before giving behavioral signs that they found the insects distasteful (Alcock, ms. submitted).

Stinkbugs, as is well-known, possess thoracic glands which are capable of secreting a volatile substance with an odor somewhat to extremely offensive depending on the species of bug and human tester. E. conspersus readily discharged its glands when handled roughly, or pecked by a bird, and several times I detected the odor coming from bugs trapped in a spider's web. This action may protect some bugs from some predators, particularly birds, which are not strongly motivated to feed. However, the insect is not solely dependent upon its secretion as it engages in a variety of defensive maneuvers - remaining immobile much of the time, scuttling under leaves or dropping from them to the ground when approached or touched, kicking at ants, buzz-flying and wing-whirring. The defensive function of the latter two behaviors is purely speculative. However, bugs flying some distance definitely produced a fairly loud and, to this observer at least, a very bee-like buzz which might deter some aerial predators from attacking. Wing-whirring consisted of lifting and rapidly vibrating the wings, producing a loud buzz. Five of a group of about fifty bugs which I picked up, handled, and returned to a leaf remained on the leaf and wing-whirred. Similar behavior has been reported for some species of stinkbugs occurring on cocoa plants (Callan, 1944) and might serve to startle or to warn a predator not to attack.

Reproductive Behavior

Only one generation of stinkbugs mated in Seattle although in California some populations have two reproductively active generations in a single summer (Borden, Madsen and Retan, 1952). The adults which overwintered in leaf litter beneath the blackberries had emerged in large numbers by the time observations were begun (midMay). Many adults and mated pairs were seen in the lot through late June but by the end of the first week in July very few adults could be found. By late July the second generation bugs were appearing in abundance with many feeding on the blackberries which were just beginning to ripen at that time.

Mated pairs were rarely seen in the morning, never at midday, and often from I 5.00 to dusk (21.00). I believe that the initiation of courtship and copulation occurred almost exclusively in the late afternoon and early evening. The mated pairs seen in the morning probably had coupled the previous evening. Hunter and Leigh 
(1965) report that in the lab bugs remain in copulo from 3-35 hours.

A total of six successful courtships was observed, largely in late May, with copulation occurring at 15.35, 18.39, 18.46, 19.27, 19.50, and 20.05. The description of courtship behavior which follows is based primarily on observations of one aggregation of between 10-2O bugs regularly present on one bracken fern in late May and early June. Courting males were active despite the cool evenings; the females present were pressed flat against the stem or leaves of the fern. Males ( I) palpated the upper surfaces of females with their antennae, (2) appeared to attempt to raise the female's abdomen by placing their heads under the side of the female and lifting upwards, and (3) turned and pressed their aedaegus, which might be completely extruded and partially inverted, against the side, belly, or tip of the abdomen of the female (or occasionally against the stem of the fern or even against another male courting the same female). These behavior patterns occurred generally in the order presented but since females were often unresponsive might be repeated over and over again.

Sometimes in response to a courting male a female would lift her abdomen slowly upward away from the surface on which it had been resting. The male would continue to court, particularly with activities (2) and (3), and often (4) palpated the undersides of the female's abdomen while standing directly behind her. This might induce the would-be mate to raise her abdomen still higher until her body formed an approximately $30^{\circ}$ angle with the stem to which she clung. At this point the male turned away and with completely extruded and inverted aedaegus backed toward the female all the while facing directly away from her. The male's abdomen was also raised and upon touching the female he pressed his aedaegus about the tip of the female's abdomen until it entered the female genital opening. After a series of small movements copulation was firmly achieved. The bugs might then move a short distance before settling down to remain in copulo for many hours.

Males were extremely persistent courters often attending to a single female for 15-30 minutes before copulation was accomplished or before the male left in search of a more receptive female. One male was watched for almost one hour as it courted without success. However, on return to the plant 45 minutes later a mated pair rested on the branch where the persistent male had been active.

Unreceptive females often simply remained flattened against a stem and did not move. Rejection of a male could be more active how- 


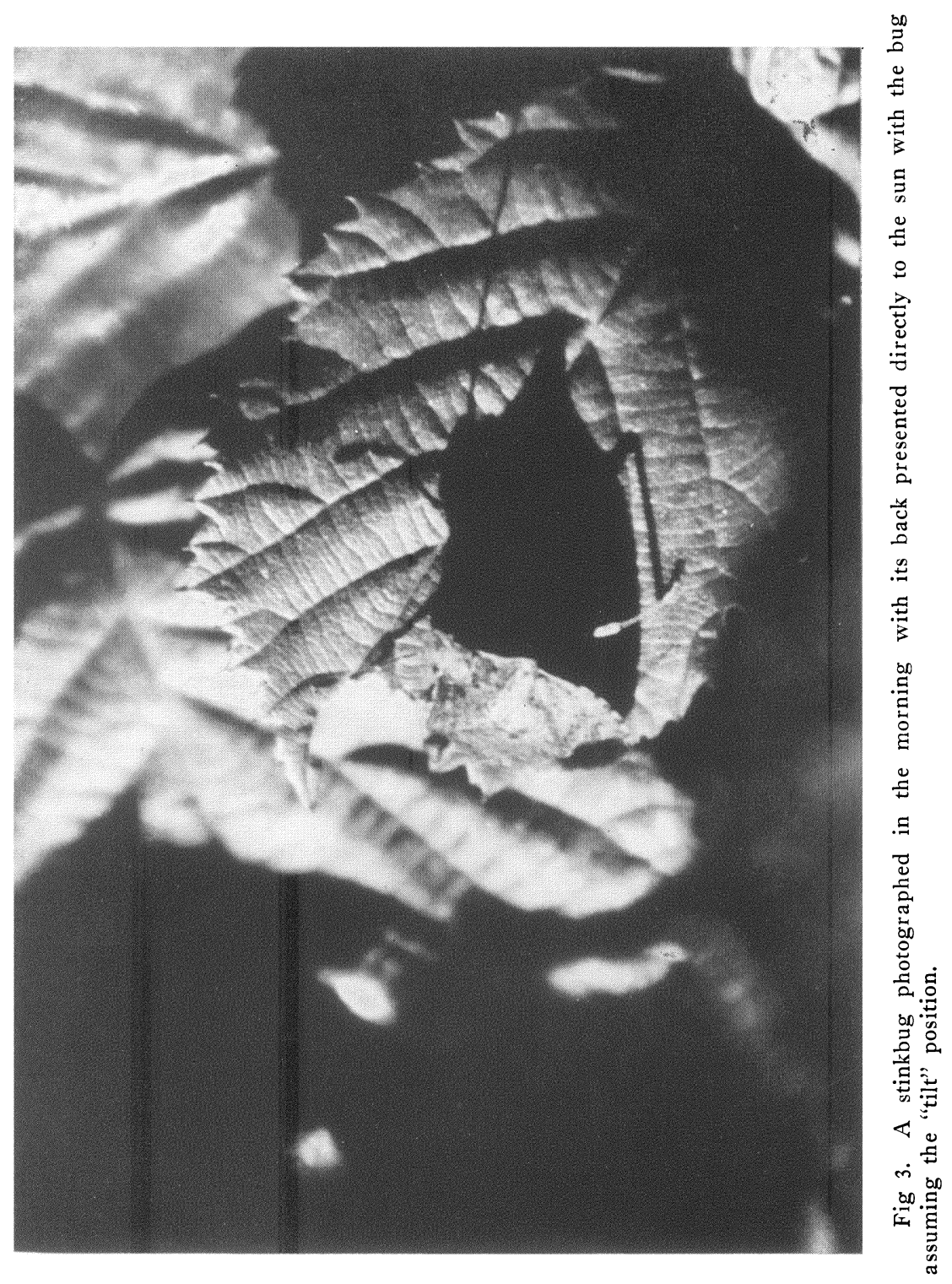


ever. Females occasionally moved their abdomens slowly from side to side or rocked back and forth as males pressed at them. One female repeatedly placed a hind leg on a male and pushed it away over a period of 45 minutes. Two females lifted their abdomens upwards but refused to permit the male aedaegus to enter their genital opening.

The Aggregation and Dispersal of E. conspersus

This stinkbug species often forms groups. As previously noted the courtship fern usually carried several bugs (during the period from 27 May to I June) although the exact number fluctuated from o to 21. Although the bugs were not marked it is at least possible that the same individuals came and went returning to the fern several times. Six meters away another bracken fern was found with another group of bugs. This aggregation was a durable one lasting from late May to I July and probably several days more. Again the number of stinkbugs present varied a good deal reaching a maximum of 30 individuals on 2 I June including 8 mated pairs at 20.30 .

Given the considerable amount of sexual activity which occurred in these first generation groups I initially felt that their function was exclusively sexual in nature. However, I later discovered that aggregations were also formed by nymphs and second-generation nonbreeding adults. Groups of 5-6 late instar nymphs could be found basking on the same leaf together, some even with their heads under the side of a companion, an action reminiscent of the abdomen lifting behavior of courting males. As fall neared large numbers of bugs (up to 6I) occurred on a single fern. Smaller contact groups of 5-IO individuals were common (Fig. 4) and one large tightly clumped cluster of between 15 and 35 bugs was found on exactly the same portion of a blackberry stem on various dates from 28 September to I7 October.

At the same time not all individuals showed a tendency to clump together in semi-permanent groups. On the contrary many E. conspersus were highly active and could be seen walking substantial distances along blackberry stems from one plant to another. On warm days in the afternoon bugs were often seen flying five to ten meters. Of 30 bugs marked on 21 May, I could find only 2 the next day. The apparent mobility and dispersal of many stinkbugs contrast sharply with the seeming stability of some groups.

Moreover, the bugs, despite sometimes forming contact groups, also could demonstrate a degree of anti-social behavior. Stinkbugs were seen kicking at each other when touched by a companion. Once one 


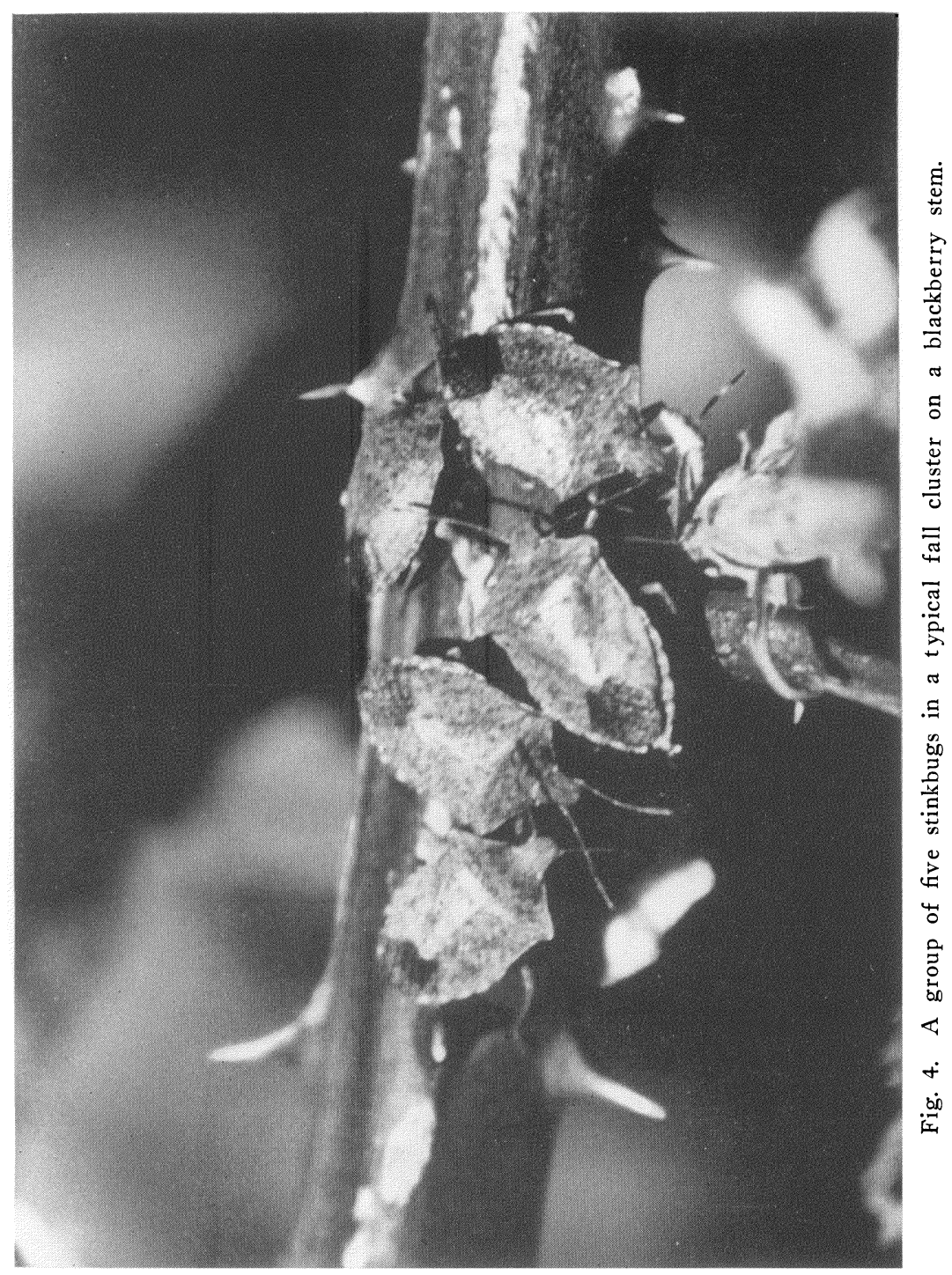


bug was observed repeatedly butting another with its head with what appeared to be aggressive intent.

Basking Behavior

\section{Discussion}

Although there have been few reports of basking by pentatomids (however see Thomas, I954) it nevertheless may be practiced quite commonly by them. Chlorochoa sayi, a less abundant stinkbug than $E$. conspersus in the study plot, also basked on blackberry leaves. This behavior is widespread among insects in general (particularly in deserts and northern latitudes where there are great temperature fluctuations). Some species, for example the desert locust (Waloff, 1963), may also orient the body to achieve maximum exposure to the sun. Basking is appropriate for the Northwest where summer nights are usually quite chilly and summer days often partly cloudy and cool.

Feeding Behavior

Although many pentatomids feed on a wide range of plant species, $E$. conspersus is the first stinkbug known to exploit a fern. Very few insects attack ferns (Brues, I920; Soo Hoo and Fraenkel, I964). The only other Heteroptera associated with ferns are some members of the mirid subfamily Bryocorinae (Southwood and Leston, I959; Woodward, Evans and Easton, 1970).

The stinkbug attacked the stems of adult bracken ferns avidly despite the fact that the plant when full grown is avoided by almost all herbivores and is reputed to be toxic to cattle (Muenscher, 1939). Moreover, bracken pinnae of at least some populations contain analogs of ecdysone (Kaplanis et al., 1967) although whether stems contain the substance is not proven. The bug's ability to feed on bracken is all the more remarkable because, unlike other fern herbivores, $E$. conspersus is not a specialist limited to ferns.

Reproductive Behavior

The courtship behavior of very few stinkbugs has been reported in any detail (but see Kullenberg, I947; Teyrovsky, I949; Southwood and Hine, 1950; Jeston, 1955; Kaufmann, 1966). Judging from these cases courtship among stinkbugs must be highly diverse. For example, the male of Calidea dregii first faces the female and then climbs forward onto her head (Kaufmann, 1966); the males of Dolycoris baccarum first creep under the abdomen of the female (Teyrovsky, 1949). However, in every previously studied case the male eventually climbs onto the back of the female and faces in the same direction 
as its partner. It is in this position that insertion of the aedaegus occurs. Usually the male then turns, dismounts and faces away from the female. Copulation proceeds in this end-to-end pose. This is a very common sequence of events among the Heteroptera in general (Grassé, 1951; Weber, 1930). E. conspersus is then the only stinkbug known to omit the male-above position and to effect a copulatory union directly end-to-end.

How might such behavior have evolved? Weber noted (1930, p. 307) that there were only two basic patterns of Hemipteran copulation - ( I) the male and female facing in the same direction with the male by the side or above the female and (2) the male and female united end-to-end facing away from each other. At the time no species was known which copulated in position (2) without first assuming the side-by-side or male-above position. From this evidence Weber argued that the end-to-end position was an elaboration of the presumably more primitive position (I). Therefore it seems reasonable that the unusual courtship pattern of E. conspersus which omits the male-above component altogether is probably a relatively recent evolutionary invention derived from the second basic pattern. Representatives of all three copulatory patterns occur in the Orthoptera (and doubtless other insect orders); Alexander's (1964) explanation for the evolution of direct end-to-end initiation of copulation in the Orthoptera is essentially the same as that outlined above for the Hemiptera.

Omission of the back-climbing phase of courtship makes some sense for pentatomids given their bulky flattened shape which could make coupling awkward in a male above/female below position (N. T. Davis, pers. comm.). Indeed in type (2) copulations the function of the male's dismounting and turning away from the female may be to achieve a more stable and easily maintained copulatory position.

Initiation of copulation directly in the end-to-end position might have had its origin in premature turning behavior. After a number of unsuccessful attempts to copulate while on the back of a female, some males might tend to dismount and turn despite the fact that coupling had not yet taken place. Teyrovsky (1949) observed a male D. baccarum attempt a direct end-to-end union with another male it had been unsuccessfully courting. Presumably in the evolution of the sexual behavior of $E$. conspersus selection first favored males with a low threshold for dismounting and turning. Gradually selection has eliminated mounting the female entirely while favoring those males which act to induce the female to assume that position which makes direct end-to-end mating most easy. 


\section{The Formation of Aggregations}

Groups of stinkbugs, both adults and nymphs, are quite well-known (Thomas, I954; Southwood and Le:ton, I959; Canerday, 1965) and appear to have multiple functions. First, mating aggregations permit males to locate or attract females of their own species ('Teyrovsky, I949; Southwood and Leston, 1959). The means by which reproductively active $E$. conspersus manage to form groups is unknown. The fact that non-reproductive individuals also clump together means that specific sex pheromones are not a necessary basis for group formation.

Second, clumping could be an anti-predator adaptation. A group of toxic, warningly-colored insects may more effectively advertize potential unpalatability than scattered individuals could. In addition should one member of a group be taken, the predator would be likely to avoid the others. However, the formation of groups by nymphs and adults of a cryptically colored species such as $E$. conspersus can hardly serve this function. As previously noted, the bug proved to be edible, although apparently distasteful, to redwinged blackbirds. The formation of groups must make these bugs more vulnerable, not less, to hungry redwings as well as to their wasp predators which can probably learn to return repeatedly to a productive searching area (Evans, 1966). The fact that the bugs are not terribly nimble also places a premium on avoiding detection by their enemies. Thus there must be some other advantage for group formation by second generation adults and nymphs which outweighs increased risk of attack by predators. What this advantage is remains uncertain. However, given the death of the ferns it seems probable that the bugs were injecting toxic substances into their foodplants as Hemiptera are known to do (Nuorteva, I958; Adams and McAllen, i968). The salivary glands of some mirids contain pectinases (Lau:ema and $\mathrm{Nu}$ orteva, I96I) as does as least one lygaeid (Adams and McAllen, I958). The pentatomid D. baccarum possesses salivary proteases and amylases (Nuorteva, I954). Thus it is possible that by feeding in groups individual bugs may extract plant juices more easily than otherwise. In any event, the relative advantages of group formation as opposed to dispersal must be rather closely balanced given the great variability in the tendency to aggregate exhibited by $E$. conspersus.

\section{SuMMARY}

This paper describes the behavior of members of one population of Euschistus conspersus Uhler, a small brown stinkbug. These bugs characteristically bask for some time after sunrise, often on black- 
berry leaves. Later in the day they feed on a wide variety of plants including bracken fern, the first pentatomid reported to attack a fern. Adults which have overwintered mate in the late afternoon and evening in May and June. Males engage in several tactile courtship activities which may induce the female to raise her abdomen upward. Males then turn away from females and back toward them with aedaegus extruded. Copulation is initiated in this end-to-end position. In all other pentatomids and most Heteroptera copulation begins with the male above the female, although later the male often dismounts and faces away from its mate. Aggregations of adults and nymphs are quite common and may have two functions - ( I) to bring reproductively active individuals together and (2) to facilitate extraction of plant juices.

\section{REFERENCES}

Allen, J. B. And J. W. McAllen

1958. Pectinase in certain insects. Can. J. Zool. 36: 305-308.

Alexander, R. D.

1964. The evolution of mating behaviour in arthropods. Roy. Entomol. Soc. Lond. Symp. 2: 78-94.

Borden, A. D., H. F. Madsen and A. H. Retan

1952. A stinkbug, Euschistus conspersus, destructive to deciduous fruits in California. J. Econ. Entomol. 45: 254-257.

BRUES, C. T.

1920. The selection of food plants by insects with special reference to lepidopterous larvae. Amer. Nat. 54: 313-332.

Callan, E. McC.

1944. Cocao stinkbugs (Hem., Pentatomidae) in Trinidad, B.W.I. Rev. Entomol. 15: 321-324.

Canerday, $T$.

1965. On the biology of the harlequin bug, Murgantia histrionica (HemEssig, E. O. iptera: Pentatomidae). Ann. Entomol. Soc. Amer. 58: 931-932.

1929. Insects of western North America. Macmillan, New York.

Evans, H. E.

Grassé, P.-P.

1966. The comparative ethology and evolut on of the sand wasps. Harvard University Press, Cambridge, Mass.

1951. Tra.té de zoologie, anatomie, systematique, biologie. Tome $\mathrm{X}$. Insectes superieurs et hemipteroides. Ordre des Heteropteres. Masson et Cie, Paris.

Hunter, R. E. AND T. F. Leigh

1965. A laboratory life history of the consperse stinkbug Euschistus conspersus (Hemiptera: Pentatomidae). Ann. Entomol. Soc. Amer. 58: $648-649$.

Kaplans, J. N., M. J. Thompson, W. E. Robbins, and B. M. Bryce

1967. Insect hormones: Alpha ecdysone and 20-hydroxyecdysone in bracken fern. Science 167: 1436-1437. 
KaUfmann, $T$.

1966. Notes on the life history and morphology of Calidea dregii (Hemiptera: Pentatomidae: Scutellerini) in Ghana, West Africa. Ann. Entomol. Soc. Amer. 59: 654-659.

KULLENBERG, B.

1947. Uber Morphologie und Funktion des Kopulationsapparats der Capsiden und Nabiden. Zool. Bidrag Fran Uppsala 24: 217-418.

Laurema, S. and P. Nuorteva

1961. On the occurrence of pectin polygalacturonase in the salivary glands of Heteroptera and Homoptera Auchenorrhyna. Ann. Entomol. Fenn. 27: 89-93.

Leston, D.

1955. The function of the conjunctiva in copulation of a shieldbug, Peizodorus lituratus (Fabricius) (Hemiptera, Pentatomidae). J. Soc. Brit. Entomol. 5 : 101-105.

Muenscher, W. C.

1939. Poisonous plants of the United States. Macmillan, New York.

Nuorteva, P.

1954. Studies on the salivary enzymes of some bugs injuring wheat kernels. Ann. Entomol. Fenn. 20: 102-124.

Nuorteva, P.

1958. Die Rolle der Speichelsekrete in Wechselverhältnis zwischen Tier und Nahrungspflanze bei Homopteren und Heteropteren. Ent. Exper. Appl. 1: 41-49.

Orians, G. H. AND H. S. Horn

1969. Overlap in foods and foraging among four species of blackbirds in the Potholes of central Washington. Ecology 50: 930-938.

Soo Hoo, C. F. and G. Fraenkel

1964. The resistance of ferns to the feeding of Prodenia eridania larvae. Ann. Entomol. Soc. Amer. 57: 788-790.

Southwood, T. R. E. ANd D. J. Hine

1950. Further notes on the biology of Sehirus bicolor (L.). Entomol. Mon. Mag. 86: 299-301.

Southwood, T. R. E. AND D. Leston

1959. Land and water bugs of the British Isles. Frederick Warne and Co., London.

Teyrovsky, V.

1949. Praeconnubia and courtship in terrestrial bugs. Acta Acad. Sci. Nat. Hist. Moravo-Silesiacae, Brno 21: 1-16.

Thомаs, D. C.

1954. Notes on the biology of Hemiptera Heteroptera. Entomologist 87: 25-30.

WALOFF, $Z$.

1963. Field studies on solitary and transiens desert locusts in the Red

WEBER, $\mathrm{H}$. Sea area. Anti-Locust Bull. no. 40.

1930. Biologie der Hemipteren. Julius Springer, Berlin.

Woodward, T. E., J. W. Evans and V. F. Eastop

1970. Hemiptera. In The insects of Australia. Melbourne University Press, Melbourne. 

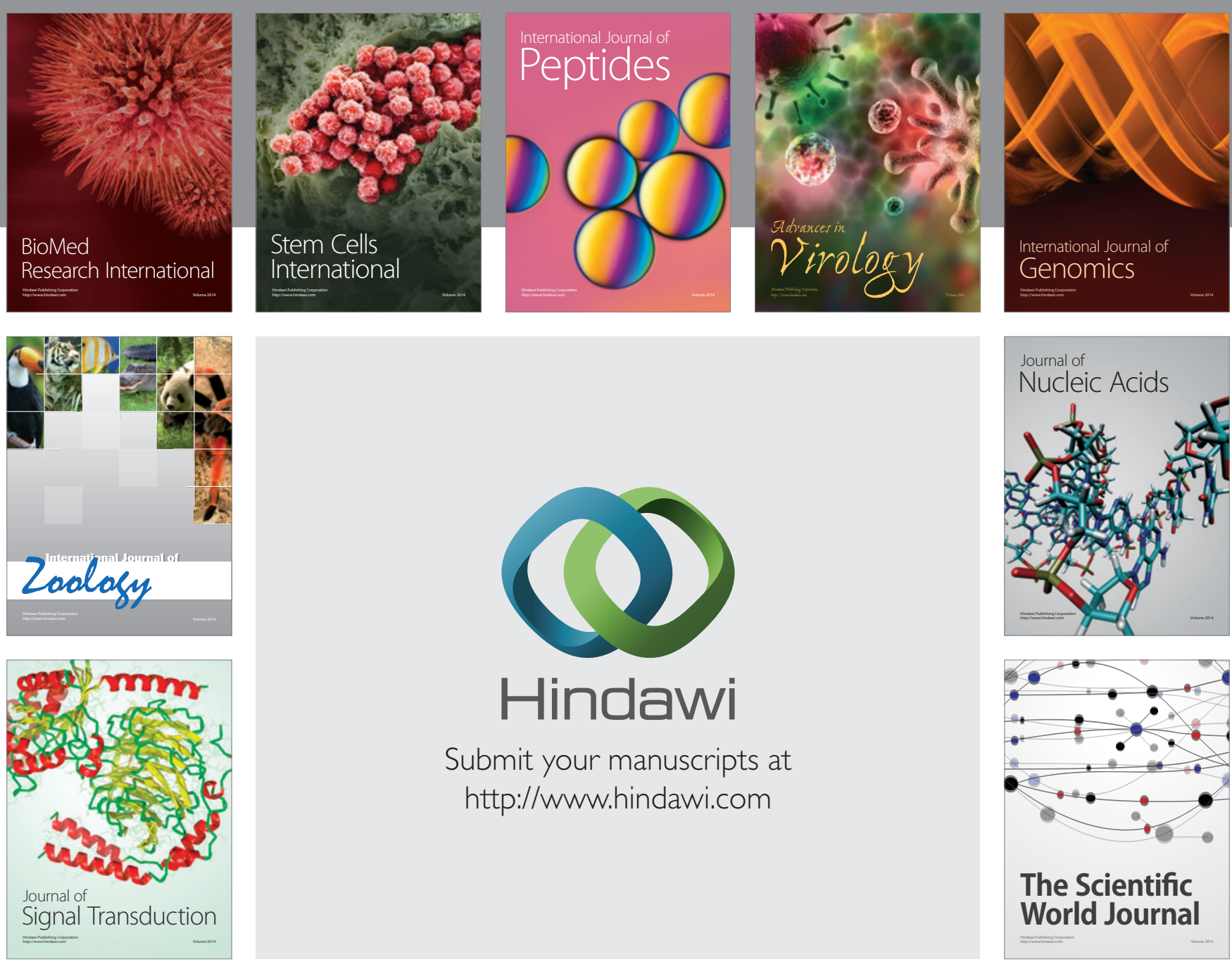

Submit your manuscripts at

http://www.hindawi.com
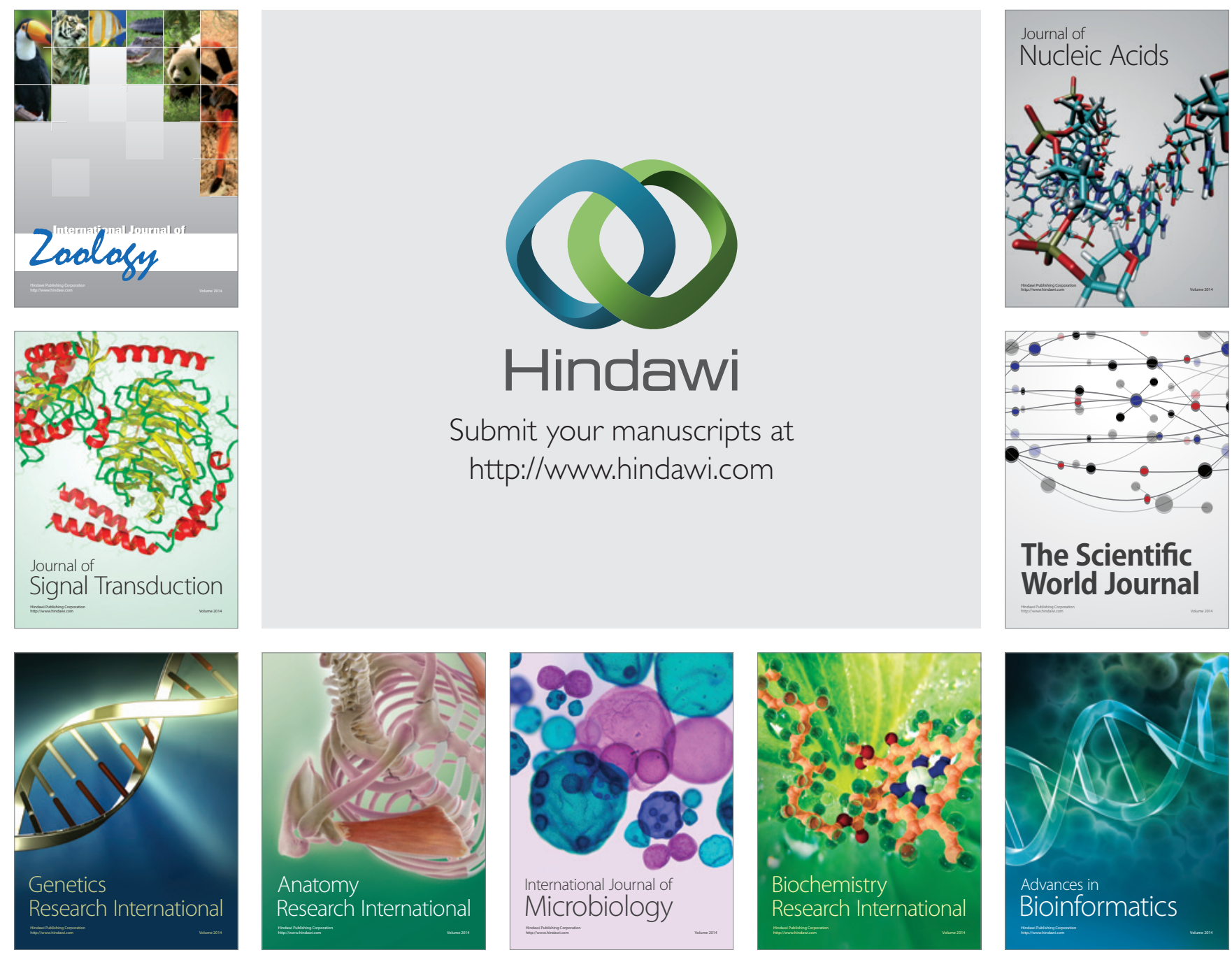

The Scientific World Journal
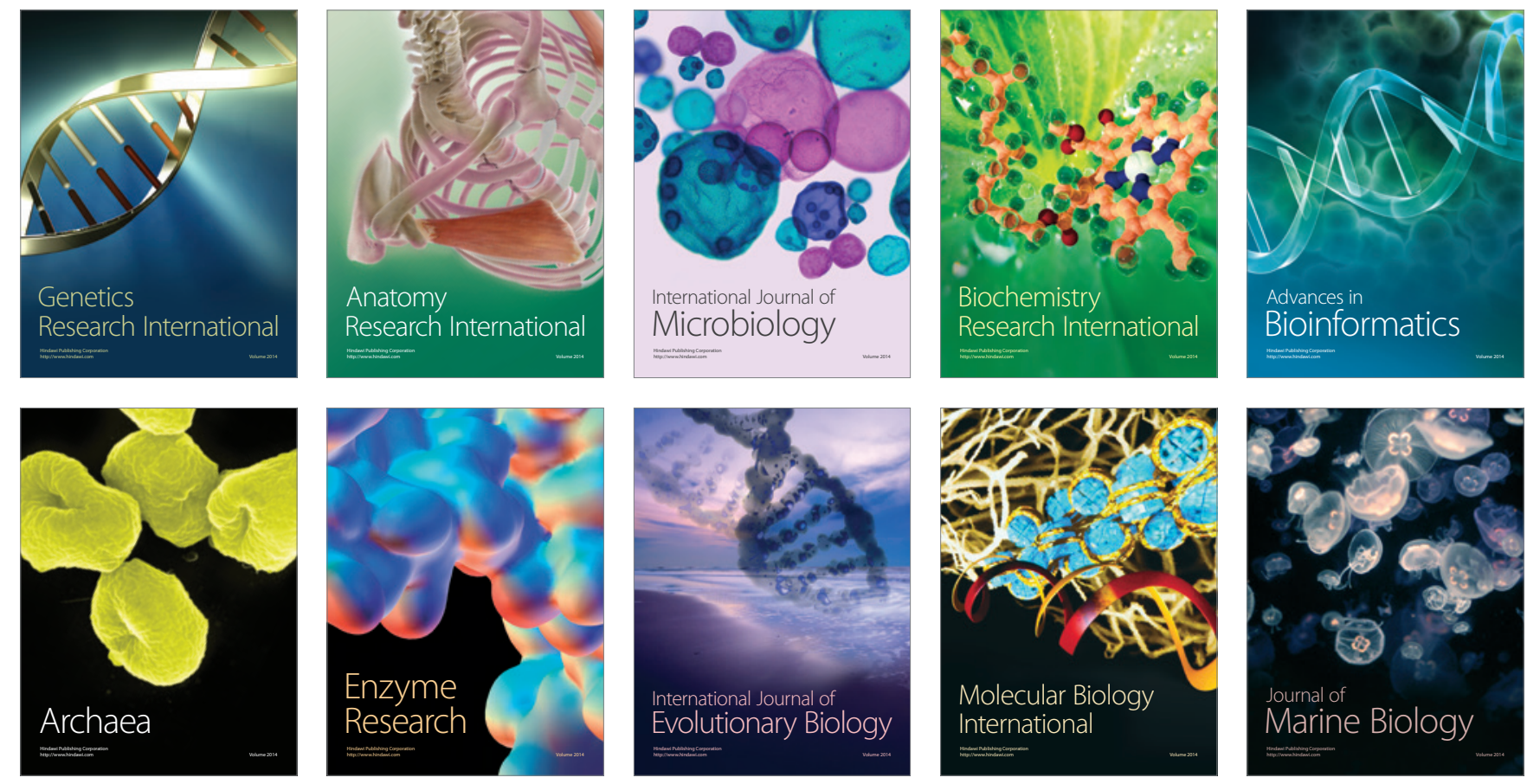